\title{
A kéz osteoid osteomáinak kivizsgálása és mútéti ellátása
}

\author{
Balog László dr. ${ }^{1}$ - Szakács Noémi dr. ${ }^{2}$ \\ Kiss János dr. ${ }^{2}$ - Hetthéssy Judit Réka dr. ${ }^{2}$ \\ ${ }^{1}$ Fejér Megyei Szent György Egyetemi Oktató Kórház, Székesfehérvár \\ ${ }^{2}$ Semmelweis Egyetem, Általános Orvostudományi Kar, Ortopédiai Klinika, Budapest
}

\begin{abstract}
Bevezetés: Az osteoid osteoma az osteochondroma és a fibrosus dysplasia után a harmadik leggyakoribb jóindulatú csonttumor, mely a legtöbb esetben típusos tünetekkel, illetve radiológiai megjelenéssel jár. Jellemző az éjszakai fájdalom, mely nemszteroid gyulladáscsökkentők adására szúnik. Képalkotó vizsgálatokon a centralis „nidus” osteolyticus zónáját reaktív sclerosis veszi körül. A kézen előfordulása ritka, jellemző tünetei hiányozhatnak, illetve atípusos tünetekkel járhat. Röntgenfelvételeken megjelenéséből szintén hiányozhatnak a típusos jellemző́k. Diagnosztikája ennek függvényében számos nehézségbe ütközhet. Klinikai/radiológiai gyanú esetén HRCT (nagy felbontású CT) vizsgálat végzése javasolt.

Célkitüzés: Célunk, hogy összefoglaljuk ezen betegség patofiziológiáját, előfordulását, klinikai jellemzőit, valamint a diagnózis felállításának nehézségeit a kézen előforduló esetekben. Tárgyaljuk továbbá az ellátási lehetőségeket.

Módszer: Retrospektív vizsgálatot végeztünk a Semmelweis Egyetem Ortopédiai Klinikáján 2014. március és 2018. december között. Beválasztási kritérium volt: osteoid osteoma miatt ellátásban részesült betegek a vizsgált periódus alatt. A kézen elhelyezkedő osteoid osteoma miatt mútéti ellátásban részesült 6 beteg anyagát esetismertetésként mutatjuk be.

Eredmények: Ezen időszak alatt a klinikánkon kezelt osteoid osteomák száma 112 volt, ebből 8 esetben (7\%) fordult elő kézen az elváltozás. A kézen előforduló elváltozások között 3 esetben hiányzott a típusos éjszakai fájdalom, valamint 1 esetben a nemszteroid gyulladáscsökkentőkre szűnő fájdalom. 6 esetben végeztünk nyitott mútéti ellátást, excochleatiót, jó eredménnyel.

Következtetés: Az osteoid osteoma előfordulása a kézen ritka, típusos tünetei elmaradhatnak, atípusos tünetek jelentkezhetnek. Radiológiai megjelenése röntgenfelvételeken szegényes lehet, klinikai gyanú esetén HRCT végzése javasolt. A rádiófrekvenciás termokoaguláció a kézen jelentkező osteoid osteomák esetén nehézségekbe ütközhet, az arany standard eljárás az excochleatio. Ezen mútét elvégzése esetén a panaszok enyhülését, megszúnését várhatjuk. Orv Hetil. 2020; 161(7): 263-268.
\end{abstract}

Kulcsszavak: osteoid osteoma, kéz, tumor

\section{Osteoid osteoma of the hand - Diagnostics and operative treatment}

Introduction: Osteoid osteoma is a rare benign bone tumor displaying typical clinical symptoms and radiological signs in most cases. Characteristic symptoms are nocturnal pain alleviated by non-steroid antiinflammatory drugs. Radiological findings are also characteristic, the central osteolytic 'nidus' is surrounded by reactive sclerosis. These lesions are rare in the hand, typical symptoms may be absent, furthermore, atypical symptoms may occur. Characteristic radiographic signs may also be missing. Therefore, diagnosis may prove difficult. In the case of radiological/clinical suspicion, HRCT (high-resolution CT) is recommended.

Aim: Our aim is to summarize the pathophysiology, occurrence and clinical features of these lesions and also the difficulties that accompany diagnosis on the hand. Treatment options will also be discussed.

Method: Retrospective analysis was performed at Semmelweis University, Department of Orthopedics, between March 2014 and December 2018. Inclusion criteria were: patients who had undergone treatment for osteoid osteoma during this period. Data from the 6 patients who have undergone open surgery for osteoid osteoma of the hand will be presented as case reports.

Results: During this period, a total of 112 patients were treated for osteoid osteoma at our Department, 8 lesions were found on the hand (7\%). Among the cases presenting on the hand, typical nocturnal pain was absent in 3 cases, and in 1 case the pain did not respond to non-steroid antiinflammatory drugs. Open surgery and curettage was performed in 6 cases with good results. 
Conclusion: Osteoid osteoma on the hand is rare, typical symptoms may be missing, and atypical symptoms may occur. Radiographic findings may be nondescript, HRCT is recommended in the case of clinical suspicion. Performing radiofrequency ablation for osteoid osteoma of the hand may pose difficulties, curettage is the gold standard of treatment. Curettage alleviates symptoms well.

Keywords: osteoid osteoma, hand, tumor

Balog L, Szakács N, Kiss J, Hetthéssy JR. [Osteoid osteoma of the hand - diagnostics, operative treatment]. Orv Hetil. 2020; 161(7): 263-268.

(Beérkezett: 2019. szeptember 23.; elfogadva: 2020. november 1.)

\section{Rövidítések}

$\mathrm{CT}=$ (computed tomography) számítógépes tomográfia; HRCT $=($ high-resolution CT) nagy felbontású CT; MR = (magnetic resonance) mágneses rezonancia; NSAID $=($ nonsteroidal anti-inflammatory drugs) nemszteroid gyulladáscsökkentő szerek; PIP = proximalis interphalangealis

Az osteoid osteoma egy kis méretú, benignus csontképző tumor (jellemzően 1,5 cm-nél kisebb). A harmadik leggyakoribb jóindulatú csonttumor, az esetek kb. 1012\%-át adja [1-4]. Irodalmi adatok alapján az osteoid osteomák kb. 50\%-a tibia- és femurdiaphysisen fordul elő $[1,4]$, s csupán kis hányaduk, kb. 5-15\%-uk fordul elő a kézen [3-6]. Az esetek kb. 75-80\%-ában 5-25 éves kor között jelentkezik [1-4]. A férfiak és a nók aránya 2-3 : 1 [1-3]. Beteganyagunkban az osteoid osteomák 7\%-a található meg a kézen (1.ábra), illetve a betegek kor szerinti megoszlása is követi az irodalmi adatokat (2. ábra).

Az elváltozás centrumában megnövekszik a ciklooxigenáz enzim aktivitása, ezért megnő a prosztaglandin E2 és a prosztaciklin szintje $[1,7]$. Ez lokálisan értágulatot, gyulladásos reakciót idéz elő, mely végső soron a beteg panaszait okozza. Szövettani képében kerek vagy ovális nidus látható, mely változó érési stádiumú osteoidokat és csonttrabeculákat tartalmaz. Az elváltozást jól vaszkularizált kötőszövet veszi körül [1].

A klinikai tünetek közül a legfőbb a jellegzetes fájdalom, mely éjszaka gyakran fokozódik, de általában nemszteroid gyulladáscsökkentők adására jól reagál [2, $6,7]$. A kézen előforduló esetekben jelentkezhet beszűkült mozgástartomány, tartós duzzanat, dobverőuji kialakulása $[4,6]$. Egyes esetekben a kéz osteoid osteomáját synovitis kísérheti.

A diagnózis felállítását segítheti az ún. szalicilátteszt, ilyenkor szalicilátszármazékok adását követően a panaszok csökkenése várható, a hatástartam idejére. Ennek alapja a fent leírt helyi gyulladásos reakció, mely NSAID adására megszünik.

A képalkotó vizsgálatok közül elsődlegesen kétirányú röntgenfelvétel elvégzése szükséges, a legtöbb osteoid osteoma esetében gyakran már ez alapján felállíthatjuk a diagnózist. A laesio centrumában osteolyticus zóna lát- ható, melyet reaktív sclerosis vesz körül [1, 7]. A kézen elhelyezkedő elváltozások esetén azonban előfordul, hogy a röntgenfelvételen hiányoznak vagy szegényesen jelennek meg a típusos radiológiai jelek. Ilyen esetekben CT-vizsgálat, illetve lehetőség szerint HRCT-vizsgálat végzése javasolt. Ez nemcsak azért indokolt, mert a CTvizsgálat az osteoid osteomára legspecifikusabb képalkotó modalitás $[1,3,8]$, hanem a preoperatív tervezést is megkönnyíti [5], illetve a kezelésben és az utánkövetésben is lehet szerepe. Az MR-vizsgálat az osteoid osteomák diagnosztikájában kevésbé specifikus, mint a CTvizsgálat $[1,3,4,8,9]$. 63\%-ban a nidus mentén a csontban, 47\%-ban pedig a lágyrészben ödéma látható. Az osteoid osteomát esetlegesen kísérő synovitis is észlelhető az MR-felvételeken [1]. A szegényes radiológiai megjelenés, illetve a kísérő jelenségek előfordulása miatt megtörténhet, hogy rosszindulatú csonttumor, stressztörés, synovitis és osteomyelitis irányában téves diagnózisok születnek [9].

Differenciáldiagnosztikája során az osteoid osteomát az alábbi kórképektől kell elkülöníteni: egyéb jó- és rosszindulatú lágyrész-, illetve csonttumorok, osteomyelitis, reumás kórképek, idegentest-reakció, Brodie-tályog, csontinfarktus, Kienböck-betegség stb. Az egyéb benignus csonttumoroktól való elkülönítése fontos lépés a diagnosztikai folyamatban, ehhez szükséges a gyakoribb elváltozások fő́bb jellemzőinek pontos ismerete. A leg-

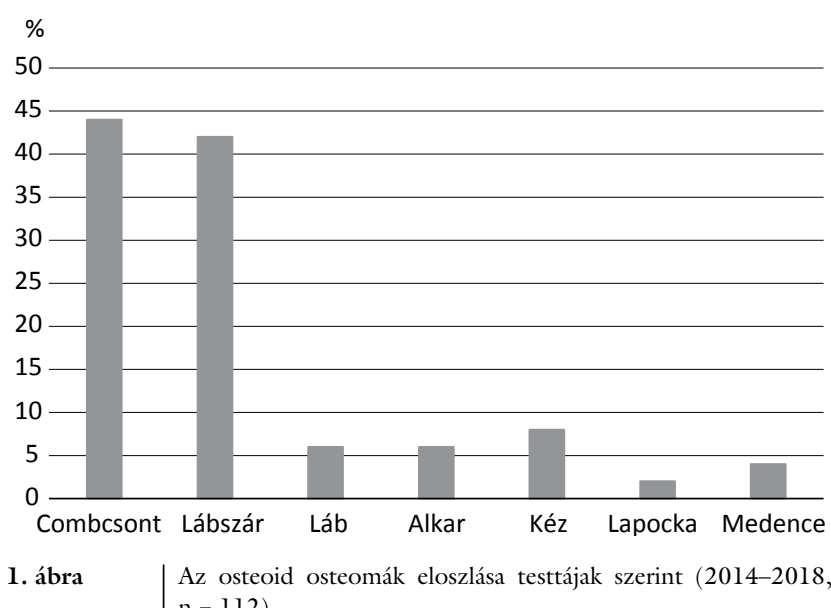

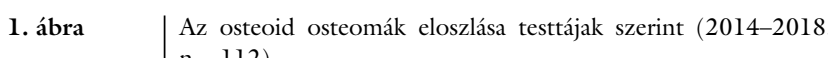




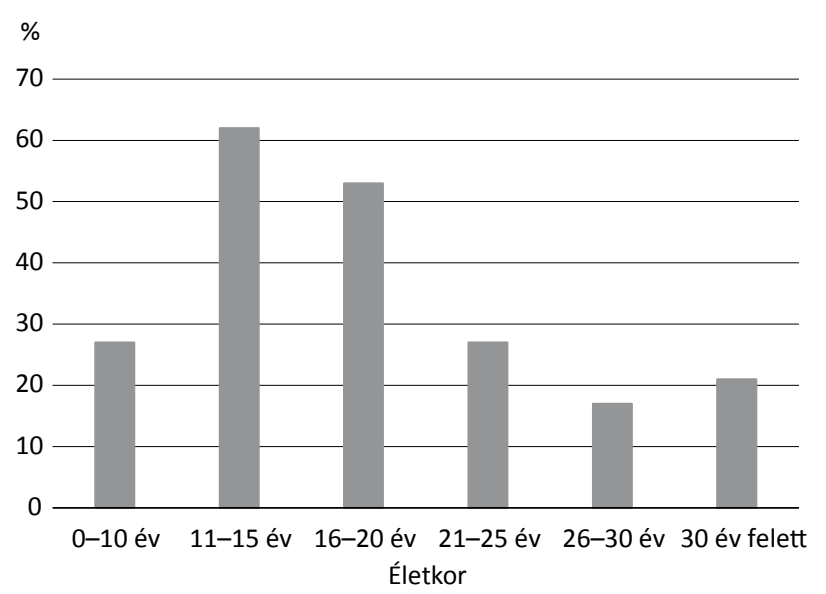

2. ábra

Az osteoid osteoma miatt kezelt betegek kor szerinti megoszlása $(2014-2018, \mathrm{n}=112)$

gyakrabban az enchondromától kell elkülönítenünk, mely a kézen található jóindulatú tumorok csaknem 90\%-a [10]. Az enchondroma jóindulatú, porcképző tumor, mely inkább a kéz csöves csontjait érinti, a carpust kevésbé. Röntgenfelvételen a csontot felfújó, a corticalist elvékonyító, chondrogen rajzolatot (pontszerú meszesedések a lyticus területeken belül) tartalmazó elváltozásként látjuk, mely az osteoid osteománál gyakran nagyobb, kiterjedtebb elváltozás, karakteresebb radiológiai képpel. Kis méretû́ elváltozások esetében azonban egymástól való elkülönítésük nehézkes lehet. Az osteomyelitis tüneteit, illetve radiológiai képét az osteoid osteoma gyakran képes utánozni, ezért a szegényes radiológiai kép a kézen különösen megnehezíti a két kórkép elkülönítését. A traumára, idegen test jelenlétére utaló anamnesztikus adatoknak, gyulladásra utaló laborparamétereknek, egyéb, az osteomyelitis kialakulását alátámasztó társbetegségeknek, állapotoknak a kizárása segítheti a megfelelő diagnózis felállítását. Az esetlegesen kialakuló kísérő synovitis, illetve dobverőujj egyéb lehetséges okainak felderítése is esszenciális része lehet az osteoid osteomák differenciáldiagnosztikájának.

A betegség természetes lefolyásából adódóan előfordulhat, hogy az osteoid osteoma kezelés nélkül is meggyógyul, évek alatt a nidus „kiérhet”, átépülhet, és ennek megfelelően a kísérő fájdalom is megszúnhet [11]. Konzervatív kezelésként nemszteroid gyulladáscsökkentők adása jöhet szóba, ez a gyakorlat azonban kevéssé terjedt el, elsősorban a hosszú távú NSAID-kezelés gastrointestinalis mellékhatásai miatt. További gyógyszeres kezelésként biszfoszfonátterápia is megtalálható az irodalomban [12], ezt azonban hazánkban nem alkalmazzuk.

Minimálinvazív módszernek számít az osteoid osteoma ellátásában a nidus percutan, CT-vezérelt felfúrása és termokoagulációja (rádiófrekvenciás ablatio), melynek célja a nidust alkotó szövet „kiégetése”. Az irodalmi adatok 90-98\% közötti sikerrátáról számolnak be, a leírt esetek zöme azonban nem a kézen található elváltozás volt. A beavatkozás a kézen a kis méretek, a szúk anatómiai viszonyok, valamint technikai nehézségek miatt nem minden esetben és lokalizációban végezhető el. Ennek a módszernek az alkalmazását tovább korlátozza, hogy a környező, hőhatásra érzékeny anatómiai képletek sérülhetnek a beavatkozás során. Végzése tehát a klinikus részéról gondos mérlegelést igényel [1, 3, 10, 13-15]. A kéz osteoid osteomái esetében az arany standard kezelés a nyitott mútéti ellátás, az excochleatio - vagyis az elváltozás maradéktalan, mind a nidust, mind a környező sclerosist magában foglaló kikaparása [16]. Más testtájakon levő osteoid osteomák esetén szóba jöhet a nidus és a környező scleroticus zóna egy blokkban történő reszekciója is, erre azonban a kéz elváltozásainál a legtöbb esetben nincs lehetőség. Amennyiben sikerül az elválto-

1. táblázat $\mid$ A Semmelweis Egyetem Ortopédiai Klinikáján 2014 és 2018 között a kézen kialakult osteoid osteoma miatt nyitott mútéti ellátásban részesült betegek adatai, panaszai, az alkalmazott kezelés, eredmények

\begin{tabular}{|c|c|c|c|c|c|c|}
\hline & H. J. & K. Zs. & G. P. & N. P. & D. M. & P. T. T. \\
\hline Kor/Nem & $22 / \mathrm{F}$ & $21 / \mathrm{F}$ & $26 / \mathrm{F}$ & $21 / \mathrm{N}$ & $21 / F$ & $16 / \mathrm{F}$ \\
\hline A panaszok kezdete & 1 év & Fél év & Fél év & 1,5 év & l év & l év \\
\hline A panaszok jellege & $\begin{array}{l}\text { Terheléstől } \\
\text { független, } \\
\text { állandó }\end{array}$ & $\begin{array}{l}\text { Idószakos, } \\
\text { szúró jellegú }\end{array}$ & $\begin{array}{l}\text { Állandó, } \\
\text { szúró jellegű }\end{array}$ & Állandó fájdalom & $\begin{array}{l}\text { Kezdetben } \\
\text { időszakos, } \\
\text { majd állandó }\end{array}$ & Állandó fájdalom \\
\hline Éjszakai fájdalom & Igen & Nem & Nem & Igen & Igen & Nem \\
\hline NSAID-ra szúnő fájdalom & Igen & $\mathrm{Nem}$ & Igen & Igen & Igen & Igen \\
\hline Képalkotó vizsgálatok & Rtg, MR, HRCT & Rtg, HRCT & Rtg, HRCT & Rtg, MR, HRCT & Rtg, MR, HRCT & Rtg, HRCT \\
\hline Az alkalmazott terápia & $\begin{array}{l}\text { RF termokoagu- } \\
\text { láció, majd } \\
\text { excochleatio }\end{array}$ & Excochleatio & Excochleatio & $\begin{array}{l}\text { Excochleatio, } \\
\text { spongiosaplastica }\end{array}$ & $\begin{array}{l}\text { Excochleatio, } \\
\text { spongiosaplastica }\end{array}$ & $\begin{array}{l}\text { Excochleatio, } \\
\text { spongiosaplastica }\end{array}$ \\
\hline Recidíva & Nincs & Nincs & Nincs & Igen & Nincs & Nincs \\
\hline Tünetmentes & Igen & Igen & Igen & Igen & Igen & Igen \\
\hline
\end{tabular}

$\mathrm{CT}$ = számítógépes tomográfia $; \mathrm{F}=$ férfi $\mathrm{HRCT}=$ nagy felbontású komputertomográfia $; \mathrm{MR}=$ mágneses rezonancia $; \mathrm{N}=$ nő; $\mathrm{RF}=$ rádiófrekvenciás; Rtg = röntgen 
zást a nidusszal együtt sikeresen eltávolítani, várható, hogy a beteg fájdalmai már a mútét utáni napokban megszünnek.

\section{Eredmények}

Retrospektív vizsgálatot végeztünk a Semmelweis Egyetem Ortopédiai Klinikáján 2014. március és 2018. december között. Azok a betegek kerültek beválasztásra, akik a megadott periódusban osteoid osteoma miatt ellátásban részesültek klinikánkon. Vizsgáltuk az osteoid osteoma kor és lokalizáció szerinti eloszlását. A kézen elhelyezkedő osteoid osteoma miatt mütéti ellátáson (feltárás, excochleatio) átesett 6 beteg anyagát mutatjuk be. A vizsgált periódus alatt a klinikánkon kezelt osteoid osteomák száma 112 volt (1. ábra). Ebból 8 esetben (7\%) fordult elő kézen az elváltozás: 5 esetben az ujjperc, 2 esetben a kézközépcsont és 1 esetben az os hamatum volt érintett. Vizsgálatunkban az osteoid osteomás betegek átlagéletkora 18,5 év (6-56 év) volt. A betegek túlnyomó többségénél a 2. és a 3. dekád között jelentkezett az elváltozás (2. ábra).

Betegeink klinikai tüneteit, kivizsgálásuk menetét, illetve ellátásukat, annak eredményességét az 1 . táblázat foglalja össze. A férfi : nő arány beteganyagunkban 5 : 1 volt. Az osteoid osteomára jellemző éjszakai fájdalom a 6 esetből csupán 3 betegnél jelentkezett. 1 beteg esetében találtunk negatív szaliciláttesztet, a többi beteg esetében a teszt az osteoid osteomákra jellegzetes pozitivitást mutatott. Mind a 6 betegnél történt röntgen- és HRCTvizsgálat, az esetek felében MR-vizsgálatot is végeztek. 5 alkalommal primeren nyitott mútétet, az elváltozás excochleatióját végeztük, melyet 3 esetben egészítettünk ki intézetünk csontbankjából származó homológ spongiosagraft beültetésével. I esetben perzisztáló klinikai panaszok és nem javuló radiológiai kép miatt reoperációt, ismételt, kiterjesztett excochleatiót végeztünk. 1 betegnél korábban történt percutan rádiófrekvenciás ablatio, majd néhány hónap után panaszai kiújultak, így excochleatiót végeztünk. Mind a 6 beteg panaszai végül szanálódtak, recidívát az utánkövetés ideje alatt nem észleltünk. A szövettani vizsgálat minden esetben igazolta az osteoid osteomát.

\section{Esetismertetés I.}

A 22 éves férfi beteg panaszai 1 évvel korábban kezdődtek. Fájdalmai diffúzan, majd a csukló ulnaris oldalára lokalizáltan jelentkeztek. Fájdalma terheléstől függetlenül jelentkezett, állandó jellegú és igen erős volt. Osteoid osteomára típusos, illetve éjszaka fokozódó fájdalmai voltak. Nemszteroid gyulladásgátlók szedése panaszait mérsékelte, azonban gastrointestinalis mellékhatások megjelenése miatt nem tudta azokat állandó jelleggel szedni. Kivizsgálása több intézményben történt. Más intézményekben készült röntgen-, CT- és MR-vizsgálatok alapján a panaszait magyarázó diagnózist felállítani nem

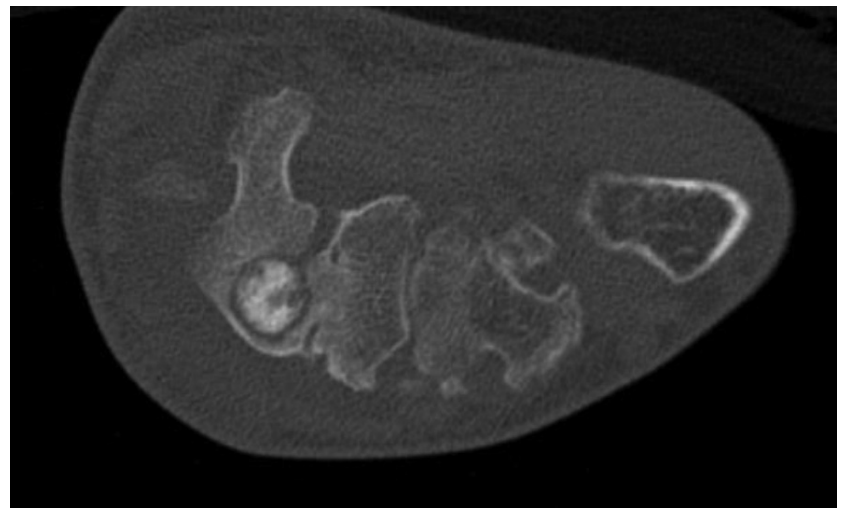

3. ábra

Az I. eset, egy 22 éves férfi jobb csuklójának CT-vizsgálata, melyen az os hamatum állományában 9 mm-es, osteoid osteomára típusos megjelenésủ elváltozás látható

$\mathrm{CT}$ = számítógépes tomográfia

sikerült. A betegnél komplex regionális fájdalom szindróma alakult ki, mely miatt konzervatív kezelést kapott, de panaszai perzisztáltak. Az intézményünkben készült HRCT az os hamatum állományában $9 \mathrm{~mm}$-es, osteoid osteomára típusos megjelenésű elváltozást írt le (3. ábra).

CT-vezérelt felfúrás és rádiófrekvenciás ablatio történt, melyek panaszait időszakosan csökkentették, ám panaszai 5 hónap múlva kiújultak. Ekkor feltárás, synovectomia és az elváltozás excochleatiója történt.

A mütétet követően éjszakai panaszai a korai posztoperatív fázisban regrediáltak, a komplex regionális fájdalom szindrómára jellemző panaszai néhány hónap alatt megszúntek. A szövettani vizsgálat során osteoid osteoma igazolódott. Jelenleg jó mozgástartomány mellett panaszmentes. Radiológiai utánkövetése zajlik, recidívát eddig nem észleltünk.

\section{Esetismertetés II.}

A 21 éves férfi beteg fél évvel korábban észlelte a bal kéz hüvelykujja végpercének duzzanatát. Fájdalmai időszakosan, szúró jelleggel jelentkeztek. Típusos éjszakai fájdalom nem volt, fájdalmai nemszteroid gyulladásgátló gyógyszerekre nem szûntek. Végpercén dobverőujj-deformitás alakult ki.

Más intézményből utalták intézetünkbe röntgenfelvétel birtokában. A hozott felvételen $2 \mathrm{~mm}$-es lyticus, scleroticus elváltozás ábrázolódott, osteoid osteomára típusos nidus nem volt látható. Tekintettel az egyértelmű diagnózist nem adó röntgenfelvételre, HRCT-vizsgálatot végeztünk, melyen osteoid osteomára típusos megjelenés, nidus ábrázolódott. Az elváltozás kis mérete miatt CT-vezérelt termokoaguláció nem jött szóba, így excochleatiót végeztünk. A szövettani vizsgálat osteoid osteomát igazolt. A beteg panaszai regrediáltak, radiológiai utánkövetése zajlik. 

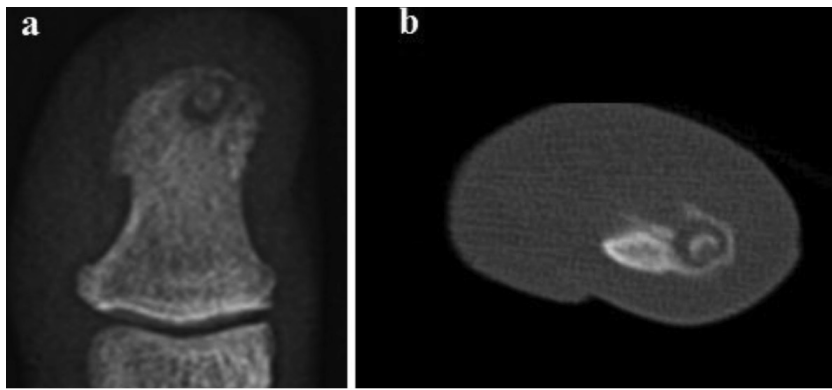

4. ábra

A III. eset, egy 26 éves férfi jobb keze hüvelykujjának röntgen(a), illetve HRCT- (b) felvétele

HRCT = nagy felbontású komputertomográfia

\section{Esetismertetés III.}

A 26 éves férfi beteg fél éve tartó jobb hüvelykujji panaszokkal jelentkezett. A fizikális vizsgálat során duzzadt, nyomásérzékeny, dobverőujjra jellemző végperc volt látható. Típusos éjszakai fájdalom nem volt, a röntgenfelvételen lyticus, scleroticus elváltozás volt látható nidussal (4. ábra), ami egyértelmúen felvetette az osteoid osteoma gyanúját. Ennek megerősítése céljából HRCT-felvétel történt.

Tekintettel az elváltozás kis méretére és lokalizációjára, CT-vezérelt termokoaguláció nem jött szóba. Feltárást, excochleatiót végeztünk. A szövettani vizsgálat osteoid osteomát igazolt. A beteg panaszai regrediáltak, radiológiai utánkövetése zajlik.

\section{Esetismertetés IV.}

A 21 éves nőbeteg panaszai 2016. ősz óta jelentkeztek a jobb kéz középső ujján. 2017. áprilisban más intézményben synovectomia és az alapperc fejecséból szövettani mintavétel történt, a szövettani vizsgálaton eltérést nem találtak. A beavatkozást követően 1 hónapig panaszmentes volt, majd ismételten erős, éjszaka is jelentkező fájdalmai alakultak ki. 2018 augusztusában jelentkezett klinikánkon. Fizikálisan a proximalis interphalangealis (PIP-) ízület feletti duzzanat, synovitis képe volt látható, az ízület 60 fokos flexiós helyzetben rögzült. Panaszait nemszteroid gyulladásgátlók valamelyest csökkentették. MR-felvételen synovitis, HRCT-n az alapperc fejecsében osteoid osteomára típusos kép volt látható. 2018. szeptemberben excochleatio és homológ spongiosaplastica történt. A posztoperatív szakban panaszai nem csökkentek, éjszakai fájdalmai megmaradtak, ízületi mozgásterjedelme nem javult. 2 hónappal később ismételt HRCTvizsgálatot követően ismételt feltárás, kiterjesztett excochleatio történt. A szövettani vizsgálat mindkét alkalommal osteoid osteomát igazolt. A beteg panaszai ezt követôen megszűntek, a PIP-ízületi contractura sajnos változatlan maradt. Radiológiai utánkövetése folyamatban van, recidíva azóta nem jelentkezett.

\section{Következtetés}

Az osteoid osteoma előfordulása a kézen ritka, az elváltozásra jellemző típusos tünetek - éjszakai fájdalom, NSAID-ra szúnő panaszok - elmaradhatnak. Nem ritka, hogy ebben a lokalizációban atípusos tünetek jelentkezhetnek. Röntgenfelvételeken megjelenése szegényes lehet, így ezek alapján egyes esetekben nem vagy nehezen diagnosztizálható. Ennek ellenére a fenti klinikai tünetek esetén gondolni kell rá, és amennyiben a klinikai gyanút röntgenfelvételek alapján megerősíteni nem tudjuk, HRCT végzése javasolt. A kézen található osteoid osteomák ellátásában a feltárás és az excochleatio az arany standard eljárás, ennek elvégzése esetén a panaszok enyhülését várhatjuk.

Anyagi támogatás: A közlemény megírása, illetve a kapcsolódó kutatómunka anyagi támogatásban nem részesült.

Szerzôi munkamegosztás: B. L.: A betegek szưrése, utánkövetése, adatelemzés, a cikk írása. Sz. N.: A betegek szürése, mútéti ellátása, utánkövetése, adatelemzés, a cikk összeállítása. K. J.: A betegek szûrése, mútéti ellátása és rádiófrekvenciás termokoagulációja, utánkövetése, adatelemzés, a tudományos munka, valamint a cikkírás szakmai felügyelete. H. J. R.: A betegek szúrése, mútéti ellátása, utánkövetése, adatelemzés, a cikk írása, a tudományos munka szakmai felügyelete. A cikk végleges változatát valamennyi szerző elolvasta és jóváhagyta.

Érdekeltségek: A szerzőknek nincsenek érdekeltségeik.

\section{Irodalom}

[1] Shaikh S, Lombay B. Osteoid osteoma: diagnosis and treatment. [Osteoid osteoma: diagnosztika és kezelés.] Magy Radiol. 2008; 82: 16-24. [Hungarian]

[2] Ozbek O, Nayman A, Koç O, et al. Radiofrequency ablation of phalangeal osteoid osteoma: technical challenges encountered in small bones. Eklem Hastalik Cerrahisi 2011; 22: 107-109.

[3] Galdi B, Capo JT, Nourbaksh A, et al. Osteoid osteoma of the thumb: a case report. Hand (NY) 2010; 5: 423-426.

[4] Andalib A, Sajadie-Khajouei S. Osteoid osteoma of distal phalanx: a rare disorder and review of literature. J Res Med Sci. 2013; 18: 264-266.

[5] Jafari D, Shariatzade H, Mazhar FN, et al. Osteoid osteoma of the hand and wrist: a report of 25 cases. Med J Islam Repub Iran 2013; 27: 62-66.

[6] Wolfe SW, Pederson WC, Kozin SH, et al. Green's operative hand surgery, 6th edition. Churchill Livingstone, London, 2011; pp. 2179-2180.

[7] Szendrói M. Tumors and tumor-like lesions of the bones and joints. [Csont-, ízületi daganatok és daganatszerü elváltozások.] Medicina Könyvkiadó, Budapest, 2015. [Hungarian]

[8] Hachem K, Haddad S, Aoun N, et al. MRI in the diagnosis of osteoid osteoma. J Radiol. 1997; 78: 635-641.

[9] Hosalkar HS, Garg S, Moroz L, et al. The diagnostic accuracy of MRI versus CT imaging for osteoid osteoma in children. Clin Orthop Relat Res. 2005; 433: 171-177. 
[10] Hsu CS, Hentz VR, Yao J. Tumours of the hand. Lancet Oncol. 2007; 8: 157-166.

[11] Goto T, Shinoda Y, Okuma T, et al. Administration of nonsteroidal anti-inflammatory drugs accelerates spontaneous healing of osteoid osteoma. Arch Orthop Trauma Surg. 2011; 131: 619625.

[12] Bousson V, Leturcq T, Ea HK, et al. An open-label, prospective, observational study of the efficacy of bisphosphonate therapy for painful osteoid osteoma. Eur Radiol. 2018; 28: 478-486.

[13] Upadhyay AR, Desai NC, Vaghela DU. Role of percutaneous computed tomography-guided radiofrequency ablation in treatment of osteoid osteoma. South Asian J Cancer 2017; 6: 139140 .
[14] Chahal A, Rajalakshmi P, Khan SA, et al. CT-guided percutaneous radiofrequency ablation of osteoid osteoma: our experience in 87 patients. J Radiol Imaging 2017; 27: 207-215.

[15] Santiago E, Pauly V, Brun G, et al. Percutaneous cryoablation for the treatment of osteoid osteoma in the adult population. Eur Radiol. 2018; 28: 2336-2344.

[16] Farzan M, Ahangar P, Mazoochy H, et al. Osseous tumours of the hand: a review of 99 cases in 20 years. Arch Bone Jt Surg. 2013; 1: 68-73.

(Hetthéssy Judit Réka dr., Budapest, Üllői út 78/B, 1082 e-mail: drhjr612@gmail.com)

\title{
MEGHÍVó
}

\section{Az Észak-Közép-budai Centrum, Új Szent János Kórház és Szakrendelő Tudományos Bizottsága tisztelettel meghívja az érdeklődőket a következő tudományos ülésére.}

\author{
Időpont: 2020. február 27. (csütörtök) 14 óra
}

\begin{abstract}
Helyszín: Szent János Kórház Auditóriuma - 1125 Budapest, Diós árok 1-3.
\end{abstract}

\author{
Üléselnök: Prof. Dr. Jánosi András
}

\section{Program}

Prof. Dr. Winkler Gábor: A 2-es típusú diabetes vércukorcsökkentő kezelése az új hazai módszertani ajánlás alapján

Dr. Schandl László osztályvezető főorvos bemutatkozó előadása

Minden érdeklődőt szeretettel várunk.

A cikk a Creative Commons Attribution 4.0 International License (https://creativecommons.org/licenses/by/4.0/) feltételei szerint publikált Open Access közlemény, melynek szellemében a cikk bármilyen médiumban szabadon felhasználható, megosztható és újraközölhető, feltéve, hogy az eredeti szerző és a közlés helye, illetve a CC License linkje és az esetlegesen végrehajtott módosítások feltüntetésre kerülnek. (SID_1) 